\title{
BILL SHACK, 1923-2000
}

The following appreciation by Elizabeth Colson and Suzanne Calpestri was written for the memorial service held in the Great Hall of the Faculty Club, University of California, Berkeley, on Thursday 6 April 2000:

William Alfred Shack, distinguished Africanist and Professor Emeritus at UC Berkeley, died on 31 March 2000 after a courageous battle with cancer. In his last months, with the assistance of his wife, Dorothy Nash Shack, he devoted himself to revising his book on African-American musicians in Paris, 1918-39. The book is now in press.

Shack, as he was known to friends and students, had a career which included field research in Ethiopia and Swaziland, teaching in a number of African and American universities, publishing several books and serving on many professional boards and as Dean of the Graduate School at Berkeley. By the time he retired there was no one on campus with a greater number of friends among faculty and administrators. $\mathrm{He}$ was known as fair-minded, imaginative, critical and helpful, all of this in a typically low-key manner that kept him very much his own person. Few who knew him probably understood the breadth of his experience or all that lay behind his appraisal of situations and people.

Shack was born in Chicago on 19 April 1923. He served in the US Coast Guard during World War II and then entered the School of the Art Institute of Chicago, where he took a B.A. in 1955. He might well have become a painter, but instead his desire to understand the social pressures of the time and a summer spent in Social Relations at Harvard University brought him into anthropology. He did an M.A. at the University of Chicago and a Ph.D. at the London School of Economics. Throughout his professional career he maintained the high standards of scholarship and attention to how social relations structure action. After taking his degree Shack returned to Ethiopia to teach at Haile Selassie University, 1962-65, and was responsible for creating its department of sociology.

Shack's scholarship, administrative talents and interest in helping students and young scholars won him recognition both in the United States and internationally. The French government honoured him as Chevalier de l'Ordre national du mérite. [Shack taught for a while at the Ecole nationale des ponts et chaussées in Paris, and directed the Education Abroad Program in Togo.] He held the Berkeley Citation and the Distinguished Service Award of the University of Chicago Alumni Association. At the 1996 annual meeting of the American Anthropological Association former students organised a panel, 'African Urban Anthropology and Beyond', that spoke to the continued influence of his thinking as well as their appreciation of his integrity and support. Throughout his career Shack had the companionship of his wife, Dorothy. She and their son Hailu were an important part of his life, sharing in his interests, which included painting and music, sports cars, university politics and cooking, along with social anthropology. 
The Ethiopian ambassador to Canada, Dr Fecadu Gadamu, was one of Shack's former colleagues, first as a fellow student of Gurage culture and then in the Department of Sociology in Addis Ababa. He writes:

It was with a great sense of shock and loss I heard of the passing of Professor Emeritus William Shack of the University of California, Berkeley. I'm sure he will be missed as much by all those who knew him or were touched by his great personal qualities-generosity and integrity as well as impeccable scholarship.

Professor Shack was a great friend of mine and a role model. We first met about four decades ago at the University of Chicago, just after he had completed his studies at the University of London and before his departure to Ethiopia to establish the Department of Sociology at the Haile Selassie I University. I was soon recruited to join him in the same department. What was established as a service department offering a minor specialisation and two freshman courses for all university students has now grown to a well established department offering both undergraduate and postgraduate degrees.

I realise my personal indebtedness to Professor Shack for his friendship, help and inspiration as I followed in his footsteps, serving in the same capacity for two and a half decades, even though the political call on my generation of academics was such that I had to answer at this time.

It was not only the establishment and development of the Sociology and Anthropology Department that is a lasting legacy of Professor Shack in Ethiopia, but also his publications on Ethiopian ethnography and contemporary issues, the best known of which are The Gurage and The Central Ethiopians.

I should add another dimension to Professor Shack's legacy. It was at the time, the early 1960s, when the university campus became hotbeds of social reformists and revolutionaries. Students' demonstration for land reform, ethnic equality, democracy, etc., seized everyone on the campus. The demands on the staff were twofold: from the students' angle, answers to the problems of the country and support for their actions. From the viewpoint of authorities, it was to act as judges of the behaviour of the students. As expected, Professor Shack participated in all these with his usual sense of integrity and fairness.

Fohn Middleton, a former Editor of Africa, has long been a member of the International African Institute's council. He writes:

Shack (as he preferred to be called by those outside his immediate family circle) was Chairman of the International African Institute between 1987 and 1996. He took his responsibilities seriously and indeed devotedly. In all that he did his personal integrity made him deeply effective, and even those colleagues who may have disagreed with him could never criticise him for dissimulation or lack of kindly humour and appreciation of the predicaments of others. 
I once watched Shack chair, with great skill, a divided and heated IAI council meeting over a horribly difficult decision that deeply affected the future of the IAI. He listened and saw all sides of the practical, legal and moral problems involved, slowly considered what should be done, took as his model early religious and philosophical leaders and activists, and finally firmly removed the issue from further pointless wrangling - as is said of chiefs in Ghana, 'he put his foot on the matter'. And that was that.

Shack was unpretentious, courteous and straightforward, a very private person who kept his own counsel and behaved towards others with thoughtfulness, respect and that old-fashioned but still meaningful word decency. He was respected by all who knew him and loved by those who were privileged to become his friends: one trusted him at first sight and one's trust was not betrayed.

\section{REFERENCES}

The Gurage: a people of the Ensete culture. London: International African Institute, 1966. This is to be reprinted in the IAI's series Classics in African Anthropology (Münster: Lit Verlag).

The Central Ethiopians: Amhara, Tigrina and related peoples, Part IV of the 'North-eastern Africa' series in the Ethnographic Survey of Africa. London: International African Institute, 1974.

Gods and Heroes: oral traditions of the Gurage of Ethiopia, translated and edited in collaboration with Habte-Mariam Marcos. Oxford: Clarendon Press, 1974.

Shack also edited, with Elliott Skinner, Strangers in African Societies (Berkeley CA: University of California Press, 1979); and, with Percy Cohen, Politics in Leadership: a comparative perspective (Oxford: Clarendon Press, 1979), in which were the essays presented at the LSE in 1975 in honour of Professor Isaac Schapera (who had taught Shack there).

Note: a slightly different, later version of the obituary by Elizabeth Colson and Suzanne Capestri was published in the May 2000 issue of Anthropology News vol. 41 , no. 5, pp. 46-7. 